\title{
The Alignment between Agricultural Policy and the SDGs: Zero Hunger and Responsible Production and Consumption in Ecuador
}

\author{
Narcisa Requelme ${ }^{1 *}$ \\ 1 Universidad Politécnica de Madrid, Spain and Universidad Politécnica Salesiana, Ecuador; nre- \\ quelme@ups.edu.ec \\ * Correspondence: nrequelme@ups.edu.ec
}

\begin{abstract}
This study reviews how policy and agricultural laws relate to Sustainable Development Goals (SDGs) 2 and 12, sustainability and rural development, in Ecuador. Policy aligns itself with goals 2 in terms of increased productivity and income (target 2,3) to international markets (targets $2 \mathrm{~b}$ y $2 \mathrm{c}$ ), rural infrastructure, research, agricultural extension and technological development (target 2a), agrobiodiversity and traditional knowledge (target 25). It is related with SDG 12 to sustainable production and consumption targets 12.1, 12.2 and 12a). Laws highlight public procurement, research, seeds, and efficient resource management through sustainable practices. It is concluded that policy is aligned with SDGs 2 and 12 but is necessary to establish others that surpass the emphasis on productivity towards export markets that leave AFC production and achieve a transition to sustainable production and consumption. The study of laws indicates that it is necessary to strengthen local governance for food sovereignty, including the peasant sectors within the framework of existing laws with participation in spaces of debate and formulation of actions.
\end{abstract}

Keywords: sustainable development; Sustainable Development Goals; public policy; agrarian policy; Ecuador.

\section{Introduction}

In 2015, the United Nations Organization issued the 2030 Agenda, an action plan for people, the planet, and prosperity [1]. The context in which it arises is different from that set by the Millennium Development Goals [2]. The factors and the content of development itself generate new constellations of power among the actors involved and condition their agency to promote the 2030 Agenda [3].

Payne [4] has noted that " $[\mathrm{w}]$ hat presently purports to be global governance is really governance of the globe by the powerful, justified by protestations about the need to offer leadership to the inhabitants of the whole of the globe". Indeed, post-Cold War global governance sought to break Western authority but without eliminating inequalities in economic power or structures of global financial and trade governance [5].

Globally, the fact that power is diffuse among non-state actors configures a dispersion in institutional structures and in markets that makes effective public control absent. G20 countries define agendas that are not completely aligned with the global agenda; hence the importance of ensuring that it is related to national policies and even to the unsustainable lifestyles that exist in both rich and emerging countries.

The ecological crisis (the excessive use of natural resources, pollution, and the alteration of ecological processes) is a direct reflection of what is produced, how it is produced, and how it is consumed. Humanitarian and social crises are largely due to unequal access to energy, resources, and opportunities needed to meet basic needs [6]. In turn, there are interactions between environmental policies and those related to household consumption 
as an indicator of poverty; according to Scherer et al. [7], satisfying human needs may mean crossing the planetary limits of resource use.

Several challenges have been identified in agriculture [8]: low productivity due to the incipient support for research, development, and innovation; insufficient response to the risks of climate change; a loss of forested areas and biodiversity; a lack of institutions that guarantee healthy competition, and a lack of trade agreements that promote price volatility, and bioeconomy as a driver of change in food and agriculture. Additionally, in Latin America, there are problems of child malnutrition due to inadequate food intake and diseases, factors that are related to food insecurity, inadequate care and feeding practices, an inappropriate domestic environment, and insufficient health services. Faced with these problematic situations, the 2030 Agenda aims to strengthen universal peace enshrined in the right to freedom; it contemplates sustainability in its economic, social, and environmental dimension; it considers people and the planet as axes of sustainable development, and it proposes a work around achieving the end of poverty and hunger, and guaranteeing equality and dignity, in addition to protecting natural resources and mitigating the effects of climate change [1].

The 2030 Agenda also states that the population should not suffer from diseases, which implies a full exercise of the right to have potable water and sanitation, and of food that is sufficient, safe, affordable, and nutritious, that is, the right to food security and sovereignty. Lastly, it encourages and seeks the implementation of sustainable consumption and production patterns.

Within the 2030 Agenda, agriculture and food are visualized as transversal axes since they cross several SDGs, i.e., 1,2,3,6, 8, 12, 13, 14, and 15 [9]. Specifically, a special dedication is proposed to develop rural areas, as well as sustainable agriculture and fishing, supporting small farmers, ranchers, and fishermen to eradicate poverty [1]. This could be achieved as long as adequate support policies for agriculture and food systems are implemented, understanding it as the sum of the various elements, activities, and actors that, through their interrelationships, make possible food production, transformation, distribution, and consumption, as well as rural development, but also the concomitant development and consolidation of global, regional, and local governance models, specifically those related to food systems, assuming this as the action of governing from a more decentralized cooperative model that includes all actors and organizations, both public and private [10].

There are several studies on governance in relation to global natural resource concerns, biodiversity, water and soils, climate change, trade regimes, food reserves and global information, competition policies and standards for foreign direct investment, research and innovation, and response and prevention of food and nutritional emergencies, as well as investments and cross-border regulations related to investments and standards on safety and health. The commitments on its approach from international governance have been agreed through various global treaties, conventions, and agreements that have important synergies. According to Von Braun and Birner [8], there are two reasons for acting globally on agricultural and food systems: one is of an economic nature and aims to address those market failures due to their transnational nature and linked to global problems such as emissions or safety standards, and food or crop enhancement via germplasm improvement; the other refers to ethical and welfare issues of the population, as in the case of food crises that exceed national capacities.

However, from the side of private non-state actors, global agreements on agriculture and food often seek to consolidate favourable scenarios that undermine the right to food; social movements propose alternatives to generate changes in the models of production and consumption, prioritizing food sovereignty as a political proposal. This is the importance of addressing the issue of governance at the local and global level, considering the criteria of all those involved in agri-food systems, since the agricultural sector is based on the adoption of effective public and governance policies [11], that is to say, in the state action tending to accomplish cooperation between the actors to achieve common objectives [12] based on participation, such as the construction of the ordinance for the use of 
public space for the commercialization of healthy products in agroecological fairs in the municipality of Cayambe.

We need to emphasize that the SDGs are global, but the policies are local [1]. Although global in scope, the SDGs require concerted efforts at the national and regional levels, and consequently each nation needs to build concrete food policy pathways and implement measures tailored to their local conditions [13]. Each country must put the regulatory margin and lead the processes in a manner compatible with the relevant international norms and commitments, so that they support each other with the objective of achieving strengthened and improved global economic governance [14]. The report "Rethinking Regional Development Policy-making" by OECD. states that the success of regional development efforts is influenced by multiple levels of governance: local, regional, national, and supranational, as well as by the participation of some intermediary organizations such as banks and non-profit organizations; the main challenge is to unite the various incentives of all the actors to provide the best support for the economic, social, and environmental development of the countries. On the other hand, there are political ambition gaps that persist in several areas of sustainable development, understood as the discrepancy between what needs to be done and what States are willing (ambitious) to do. Therefore, many argue that the actions of non-state actors, such as companies and investors, cities and regions, and non-governmental organizations, are crucial. The relationship between non-state action and traditional governance may evolve differently in sustainable development and climate governance, which probably requires multiple and personalized strategies.

Furthermore, these strategies are not strictly related to policy formulation, but also drive more research for better governance with non-state actors, focusing on the multiple and complex interactions between actors in a fragmented governance environment [15].

The SDGs are not only challenging in terms of magnitude, complexity, and ambition, but they also require significant budget, knowledge, and resources that governments and/or other actors may lack. With the adoption of the 2030 Agenda, public-private collaboration has become strategic for at least two reasons. First, public-private partnerships have the potential to become key agents in bridging the current massive infrastructure gap by providing profitable financing capabilities, services, and infrastructure, and because they tend to be more willing to take risks. Second, in addition to their current value for accessing financial means, public-private partnerships also have the potential to create social value or value for people by incorporating social goals beyond the common market [16].

The 2030 Agenda contains 17 SDGs, 169 targets and 230 indicators of an integrated and indivisible nature; they consider the reality, capacities, and levels of each country, respecting their national policies and priorities. However, the global nature of the SDGs leaves countries free to define their local agendas, which can lead to different levels of compliance and to the non-specification of actions or policies to underpin common global problems.

The SDGs are intentionally framed in general terms, following the idea of countryled implementations. As policies are generally implemented at the sub-national level, the SDGs should not be overly prescriptive, but should offer guidelines adaptable to specific contexts [17]; in other words, the development of the countries must focus on policies that are articulated with the SDGs, which requires designing adequate solutions for each territory and economic and social context [18].

The SDGs are also a planning tool, both nationally and locally, and actions cannot be disjointed. Thanks to their long-term vision, they will constitute a support for each country on its path towards sustained, inclusive development and in harmony with the environment through public policies and budget, monitoring, and evaluation instruments [19].

In the field of agriculture and rural development, the achievement of the SDGs has multiple implications and interrelationships; in terms of opportunities and challenges of food systems governance, FAO proposed to work on SDGs 1, 2, 12, and 17. Among these 
objectives, SDGs 2 and 12 are key as they are the foundation for the survival of the world population. They seek to achieve food security and sovereignty (SDG 2) based on sustainable agriculture production models, accompanied by responsible consumption (SDG 12), guaranteeing access and control of productive resources, land, and water, protecting fertility of soils and agrobiodiversity, and articulating countryside and cities as sustainable economic interweaved structures. But the challenges of guaranteeing food security and sovereignty also involve achieving water and energy security. This is increasingly complex due to climate changes that affect the water regime and energy use by increasing competition for land, water, bioenergy, and hydroelectric power (SDG 7) [19].

A close relationship exists between these objectives and SDG 13, since emissions must be reduced and transformative actions are needed in food systems that involve technical, policy, capacity improvement, and financial elements [20,21]. On the other hand, when talking about adaptation to climate change, the systems approach is suggested as a proposal to plan community development, where the coordination of actions at different spatial scales, jurisdictional levels, and sectors is proposed; but it is a proposal where incremental adaptation strategies are included to overcome systemic causes that have institutional and political roots of disadvantage for small producers. Achieving SDG 2 also involves thinking about other areas of natural resource use, such as bioenergy production, that occupy spaces that once where destinated to food production [22].

Achievement of objectives 2 and 12 would contribute concomitantly to the achievement of other objectives such as the end of poverty (SDG 1), since producers can selfsustain their food and generate surpluses to obtain income (SDG 8) and to cover other needs around health and well-being (SDG 3), quality education (SDG 4), decent work, reduction of inequalities (SDG 10), actions in favour and climate (SDG 14), and peace (SDG 16).

The governments that support the Agenda are responsible for ensuring policy coherence with the SDGs [23]. The SDGs are now the main benchmark for development policies and programs at the national level. Therefore, the objective is that public policies and their corresponding budgetary allocations be guided by the SDGs that allow them to be managed, since the lack of them is a barrier to overcome financial gaps for the development and generation of comprehensive policies for the implementation of the 2030 Agenda. The Community of Latin American and Caribbean States has defined as a priority the enhancement of means for the execution and integration of the SDGs in the national development plans and budgets of each country. This requires a diagnosis of how aligned the policies that are already in place are, where the degree of correspondence and areas of improvement are identified for a reorientation or progressive alignment of existing policies, and for promoting an acceleration towards achieving the 2030 Agenda.

On the other hand, policies are a crucial ingredient for learning and cooperation; these are needed to implement development projects and increase the resilience of communities [24]. Furthermore, the creation of policy networks is considered a key objective of local collaborative governance, which has become a development strategy to be applied in programs, whether governmental or not [13].

This study seeks to know, for the first time, how the SDGs, specifically SDG 2 and SDG 12, are incorporated as a frame of reference for current agricultural planning and policy aimed at promoting rural development in Ecuador, as a necessary step for a sustainable development strategy in the agricultural sector. This descriptive-analytical study reviews the 2017-2021 National Development Plan, the policies, and the main laws in force related to the agricultural sector and shows how the goals established in State planning fit into the SDGs related to hunger reduction and to sustainable consumption and production that contribute to the promotion of sustainability and rural development in Ecuador.

\section{Materials and Methods}

The higher level relationships were analysed between the 2017-2021 National Development Plan and SDGs 2 and 12, and those at a lower level between them and the current 
agricultural policy (Figure 1); the Nvivo program (https://www.qsrinternational.com/nvivo-qualitative-data-analysis-software/home) was applied as a search engine for keywords related to each target of the objectives (Table 1), but no sentences or paragraphs were used as happens with other programs [25].

Table 1. Referential search keywords

\begin{tabular}{|c|c|c|}
\hline Target & UN definition & Keywords \\
\hline \multicolumn{3}{|c|}{ SDG 2: END HUNGER, ACHIEVE FOOD SECURITY AND } \\
\hline \multicolumn{3}{|c|}{ IMPROVED NUTRITION AND PROMOTE SUSTAINABLE AGRICULTURE } \\
\hline 2.1 & $\begin{array}{l}\text { By } 2030 \text { end hunger and ensure access by all people, in } \\
\text { particular, the poor and people in vulnerable situations in- } \\
\text { cluding infants, to safe, nutritious, and sufficient food all } \\
\text { year round }\end{array}$ & poverty, hunger \\
\hline 2.2 & $\begin{array}{l}\text { By 2030, end all forms of malnutrition, including achiev- } \\
\text { ing, by 2025, the internationally agreed targets on stunting } \\
\text { and wasting in children under } 5 \text { years of age, and address } \\
\text { the nutritional needs of adolescent girls, pregnant and lac- } \\
\text { tating women, and older persons }\end{array}$ & $\begin{array}{c}\text { malnutrition, under- } \\
\text { nourishment }\end{array}$ \\
\hline 2.3 & $\begin{array}{l}\text { By } 2030 \text {, double the agricultural productivity and incomes } \\
\text { of small-scale food producers, in particular women, indig- } \\
\text { enous peoples, family farmers, pastoralists, and fishers, in- } \\
\text { cluding through secure and equal access to land, other } \\
\text { productive resources and inputs, knowledge, financial ser- } \\
\text { vices, markets and opportunities for value addition and } \\
\text { non-farm employment }\end{array}$ & $\begin{array}{l}\text { productivity, in- } \\
\text { come, land, seed, } \\
\text { knowledge, finan- } \\
\text { cial services, market }\end{array}$ \\
\hline 2.4 & $\begin{array}{l}\text { By } 2030 \text {, ensure sustainable food production systems and } \\
\text { implement resilient agricultural practices that increase } \\
\text { productivity and production, that help maintain ecosys- } \\
\text { tems, that strengthen capacity for adaptation to climate } \\
\text { change, extreme weather, drought, flooding and other dis- } \\
\text { asters and that progressively improve land and soil qual- } \\
\text { ity }\end{array}$ & $\begin{array}{l}\text { sustainability, sus- } \\
\text { tainable, resilience, } \\
\text { ecosystems, climate }\end{array}$ \\
\hline 2.5 & $\begin{array}{l}\text { By 2020, maintain the genetic diversity of seeds, cultivated } \\
\text { plants, and farmed and domesticated animals and their re- } \\
\text { lated wild species, including through soundly managed } \\
\text { and diversified seed and plant banks at the national, re- } \\
\text { gional and international levels, and promote access to and } \\
\text { fair and equitable sharing of benefits arising from the utili- } \\
\text { zation of genetic resources and associated traditional } \\
\text { knowledge, as internationally agreed }\end{array}$ & $\begin{array}{l}\text { seeds, germplasm, } \\
\text { genetic resources, } \\
\text { traditional } \\
\text { knowledge }\end{array}$ \\
\hline 2.a & $\begin{array}{l}\text { Increase investment, including through enhanced interna- } \\
\text { tional cooperation, in rural infrastructure, agricultural re- } \\
\text { search and extension services, technology development } \\
\text { and plant and livestock gene banks in order to enhance } \\
\text { agricultural productive capacity in developing countries, } \\
\text { in particular least developed countries }\end{array}$ & $\begin{array}{l}\text { research, technol- } \\
\text { ogy, irrigation, } \\
\text { agrarian extension, } \\
\quad \text { germplasm }\end{array}$ \\
\hline
\end{tabular}




\begin{tabular}{|c|c|c|}
\hline Target & UN definition & Keywords \\
\hline $2 . b$ & $\begin{array}{l}\text { Correct and prevent trade restrictions and distortions in } \\
\text { world agricultural markets, including through the parallel } \\
\text { elimination of all forms of agricultural export subsidies } \\
\text { and all export measures with equivalent effect, in accord- } \\
\text { ance with the mandate of the Doha Development Round }\end{array}$ & $\begin{array}{l}\text { market, subsidies, } \\
\text { imports }\end{array}$ \\
\hline 2.c & $\begin{array}{l}\text { Adopt measures to ensure the proper functioning of food } \\
\text { commodity markets and their derivatives and facilitate } \\
\text { timely access to market information, including on food re- } \\
\text { serves, in order to help limit extreme food price volatility }\end{array}$ & $\begin{array}{l}\text { markets, food secu- } \\
\text { rity, food sover- } \\
\text { eignty, prices }\end{array}$ \\
\hline \multicolumn{3}{|c|}{ SDG 12: ENSURE SUSTAINABLE CONSUMPTION AND PRODUCTION PATTERNS } \\
\hline 12.1 & $\begin{array}{l}\text { Implement the 10-Year Framework of Programs on Sus- } \\
\text { tainable Consumption and Production Patterns, all coun- } \\
\text { tries acting, with developed countries taking the lead, con- } \\
\text { sidering the development and capabilities of developing } \\
\text { countries }\end{array}$ & $\begin{array}{l}\text { sustainable con- } \\
\text { sumption }\end{array}$ \\
\hline 12.2 & $\begin{array}{c}\text { By 2030, achieve the sustainable management and efficient } \\
\text { use of natural resources }\end{array}$ & $\begin{array}{l}\text { sustainable devel- } \\
\text { opment, efficient } \\
\text { use }\end{array}$ \\
\hline 12.3 & $\begin{array}{l}\text { By } 2030 \text {, halve per capita global food waste at the retail } \\
\text { and consumer levels and reduce food losses along produc- } \\
\text { tion and supply chains, including post-harvest losses }\end{array}$ & waste, losses \\
\hline 12.4 & $\begin{array}{l}\text { By } 2020 \text {, achieve the environmentally sound management } \\
\text { of chemicals and all wastes throughout their life cycle, in } \\
\text { accordance with agreed international frameworks, and } \\
\text { significantly reduce their release to air, water and soil in } \\
\text { order to minimize their adverse impacts on human health } \\
\text { and the environment }\end{array}$ & residues, waste \\
\hline 12.5 & $\begin{array}{c}\text { By } 2030, \text { substantially reduce waste generation through } \\
\text { prevention, reduction, recycling, and reuse. }\end{array}$ & $\begin{array}{l}\text { waste, reduction, re- } \\
\text { cycling, reuse }\end{array}$ \\
\hline 12.6 & $\begin{array}{c}\text { Encourage companies, especially large and transnational } \\
\text { companies, to adopt sustainable practices and to integrate } \\
\text { sustainability information into their reporting cycle. }\end{array}$ & Businesses \\
\hline 12.7 & $\begin{array}{l}\text { Promote public procurement practices that are sustaina- } \\
\text { ble, in accordance with national policies and priorities }\end{array}$ & $\begin{array}{l}\text { public procurement, } \\
\text { food security }\end{array}$ \\
\hline 12.8 & $\begin{array}{l}\text { By 2030, ensure that people everywhere have the relevant } \\
\text { information and awareness for sustainable development } \\
\text { and lifestyles in harmony with nature. }\end{array}$ & $\begin{array}{l}\text { sustainable devel- } \\
\text { opment, styles }\end{array}$ \\
\hline 12.a & $\begin{array}{l}\text { Support developing countries to strengthen their scientific } \\
\text { and technological capacity to move towards more sustain- } \\
\text { able patterns of consumption and production }\end{array}$ & research, technology \\
\hline $12 . b$ & $\begin{array}{l}\text { Develop and implement tools to monitor sustainable de- } \\
\text { velopment impacts for sustainable tourism that creates } \\
\text { jobs and promotes local culture and products }\end{array}$ & tourism, work \\
\hline
\end{tabular}




\begin{tabular}{ccc}
\hline Target & \multicolumn{1}{c}{ UN definition } & Keywords \\
\hline 12.c & Rationalize inefficient fossil-fuel subsidies that encourage & subsidies, busi- \\
& wasteful consumption by removing market distortions, in & nesses \\
& accordance with national circumstances, including by re- & \\
structuring taxation and phasing out those harmful subsi- & \\
& dies, where they exist, to reflect their environmental im- \\
pacts, taking fully into account the specific needs and con- & \\
ditions of developing countries and minimizing the possi- & \\
ble adverse impacts on their development in a manner & \\
that protects the poor and the affected communities & \\
\hline
\end{tabular}

Qualitative techniques were used to collect secondary information from State institutional sources and primary information generated through semi-structured interviews with public officials of the Agriculture and Livestock Ministry (MAG), FAO Ecuador, Interamerican Institute for Cooperation on Agriculture (IICA) and social organizations on institutional structure, regulations, management models, and strategies and guidelines of the current agricultural policy in order to corroborate the relations of the officially defined policy with what is implemented in relation to the 2 y 12 SDGs as shown in the results.

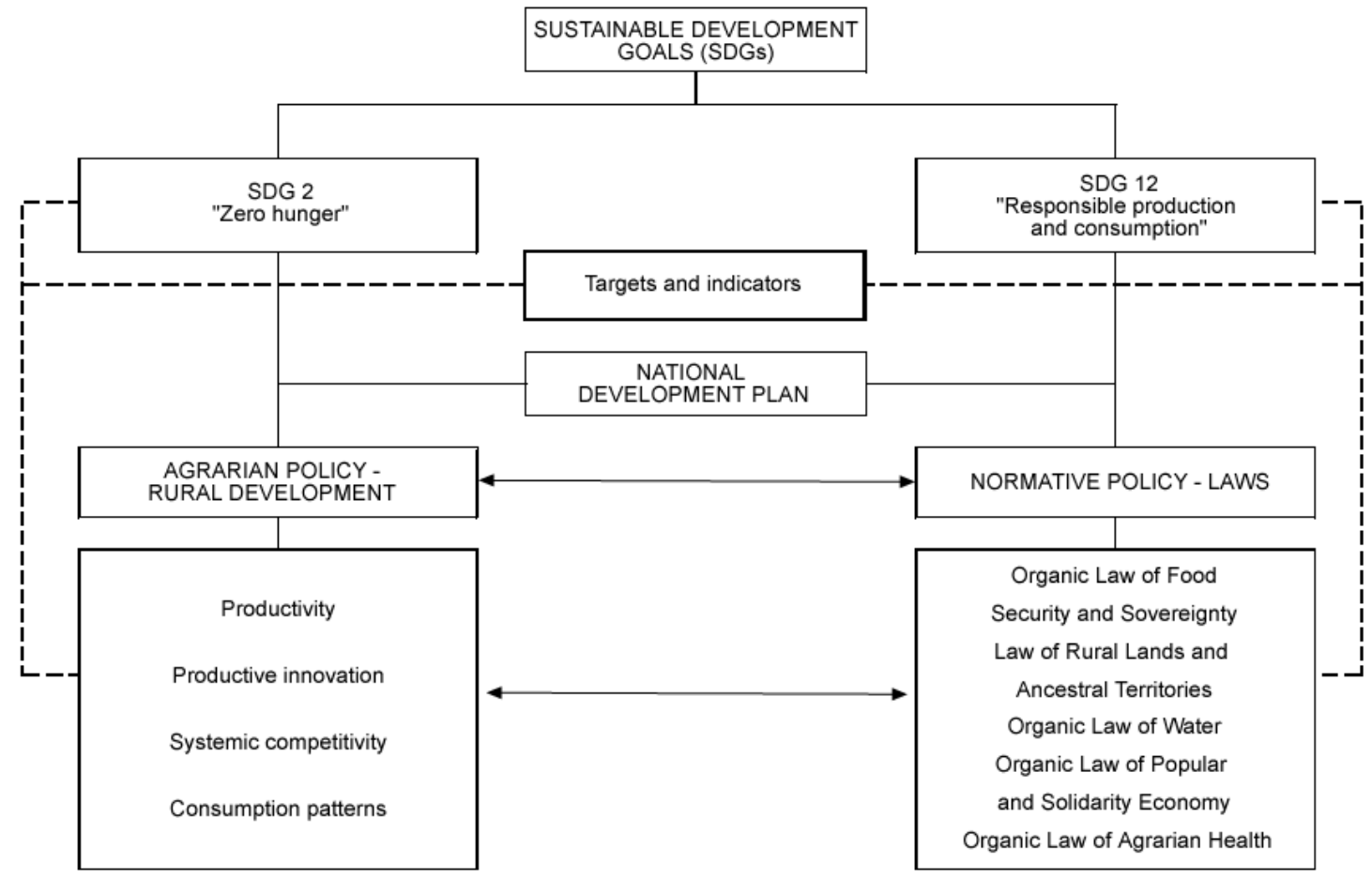

Figure 1. Research logic.

The following current laws related to access to basic productive resources and those associated with the production, quality, and marketing model of products were chosen for the analysis, which have an 'organic' label due to their high importance in food and rural development issues. The processes of construction of these laws, except for the LOSA Law, were motivated by various social groups and peasants who promoted them and influenced the decision makers to incorporate their visions. Despite this, some do not 
fully respond to the peasant proposals because they maintain an alignment with the current development model with an emphasis on economic issues.

Table 2. Laws in force herein analysed

\begin{tabular}{|c|c|c|c|}
\hline No. & Name & Year & Objective \\
\hline 1 & $\begin{array}{l}\text { Organic Law of Food } \\
\text { Sovereignty Regime }\end{array}$ & 2010 & $\begin{array}{l}\text { Establish mechanisms to guarantee people, communities, } \\
\text { and peoples self-sufficiency in healthy, nutritious and } \\
\text { culturally appropriate food on a permanent basis. }\end{array}$ \\
\hline 2 & $\begin{array}{l}\text { Law on Agrobiodiversity, } \\
\text { Seeds and Promotion of } \\
\text { Sustainable Agriculture }\end{array}$ & 2017 & $\begin{array}{l}\text { Protect, revitalize, multiply and energize agrobiodiver- } \\
\text { sity, specifically with regard to plant genetic heritage for } \\
\text { food and agriculture, seeking to ensure free access to } \\
\text { quality and variety seeds, and regulate sustainable agri- } \\
\text { culture models respecting identity, knowledge and an- } \\
\text { cestral knowledge, all this in order to guarantee food } \\
\text { sovereignty. }\end{array}$ \\
\hline 3 & $\begin{array}{c}\text { Organic Law of Rural } \\
\text { Lands and Ancestral Ter- } \\
\text { ritories }\end{array}$ & 2016 & $\begin{array}{l}\text { Regulate the use and access to rural land property, en- } \\
\text { suring that it fulfils its social and environmental func- } \\
\text { tion, and also regulates the possession, ownership, ad- } \\
\text { ministration, and redistribution of rural land as a factor } \\
\text { of production to guarantee food sovereignty. }\end{array}$ \\
\hline 4 & Organic Water Law & 2014 & $\begin{array}{l}\text { Guarantee the human right to water, as well as regulate } \\
\text { and control the authorization, management, preserva- } \\
\text { tion, conservation, and restoration of water resources, } \\
\text { use and exploitation of water, comprehensive manage- } \\
\text { ment and recovery in order to guarantee the Sumak } \\
\text { Kawsay [Good Life] and the rights of Nature }\end{array}$ \\
\hline 5 & $\begin{array}{l}\text { Organic Law of Popular } \\
\text { and Solidarity Economy }\end{array}$ & 2011 & $\begin{array}{l}\text { Recognize, promote, and strengthen this type of econ- } \\
\text { omy, the solidarity financial sector, promote these prac- } \\
\text { tices and establish the legal framework to protect related } \\
\text { organizations. }\end{array}$ \\
\hline 6 & $\begin{array}{c}\text { Organic Law on Agricul- } \\
\text { tural Health }\end{array}$ & 2017 & $\begin{array}{l}\text { Regulate agricultural health, applying measures to pre- } \\
\text { vent the entry, spread, control, and eradication of pests } \\
\text { and diseases that affect plants and animals, and promote } \\
\text { animal welfare. }\end{array}$ \\
\hline
\end{tabular}

\section{Results and Discussion}

\subsection{National planning and SDGs}

FAO accompanies Ecuador in the process of articulating the SDGs with the National Development Plan 2017-2021 in three priority areas: food and nutritional security; agriculture and rural development, and natural resource management and risk management, which encompass SDGs 2,5,6,12,14 and 15. The country, in its first voluntary report of 2018, on the progress of SDGs 1,2,6,7,11.12.15 and 17 reports a reduction in poverty from 51.5 to $35.1 \%$ between 2014 and 2017. Early childhood care is proposed as a challenge to reduce chronic malnutrition, obesity, and overweight problems in children, as well as specific policies within the National Development Plan not necessarily linked to SDGs 2 and 12. There is also an increase in the percentage of homes supplied with water by public network from $66.4 \%$ in 2014 to $71.9 \%$ in 2017 (SDG 6). It is proposed as a policy to guarantee the fair, equitable, and sustainable access, use, and exploitation of water, its availability, especially for its use in food production through irrigation systems.

In relation to SDG 12, it is mentioned that there is a reduction in the gap of the ecological footprint and biocapacity, registering an increase of 0.70 global ha (gha) per capita 
in 2014 to $0.74 \%$ in 2016, but registering a decrease to $0.57 \%$ in 2017 and to $0.54 \%$ gha in 2018. Consider that globally, as of 2010, there was a deficit of 3.9 trillion gha and 0.6 gha per capita, while in the Andean Community it was 288.9 million gha and 3 gha per capita. The issue of food, both in the ways of production and quantity, plays an important role since it represents $26 \%$ of humanity's global capacity. Specific policies propose mechanisms to improve alternative marketing circuits for Family Farming Agriculture (FFA), support to organizations and social responsibility in access to natural resources, crop losses, food waste, and the management of hazardous chemicals and wastes such as agricultural chemical pesticides. Another policy that goes hand in hand with SDG 12 is that related to the resilience of communities, which seeks to address vulnerability with a focus on food security, climate change, and local planning and integrated management to control desertification and soil degradation.

Compliance with SDG 15 is notorious: there is an increase in the area that is conserved in hydrographic basins from $31.1 \%$ in 2014 to $32.6 \%$ in 2017 . Progress is also reported by the National Secretariat for Planning and Development in compliance with SDG 1, with a multidimensional poverty rate that in 2014 was $37.4 \%$ and fell to $34.6 \%$ in 2017 .

\subsection{Ecuadorian agrarian Policy and SDGs}

The Ecuadorian Constitution recognizes the Rights of Nature and declares that the State is plurinational and intercultural, which implies establishing the concepts of inclusion, sustainability, and democracy at all levels. A new production model is proposed that prioritizes the reproduction of life and, where possible, competition with solidarity, complementarity, and social justice. Community principles are collected to apply a new endogenous accumulation and redistribution strategy to satisfy basic needs. Consequently, the Ministry of Agriculture and Livestock (formerly Ministry of Agriculture, Livestock, and Fisheries) designed the agricultural policy in 59 guidelines contained in four areas: a) policies that generate conditions for generational replacement; b) policies that influence structural factors in agriculture; c) policies that take advantage of the agricultural potential and face the conflict of land use, and d) complementary policies that underpin rural territorial development. The objective is to reverse the structural trends of the exclusive agrarian model by a new one that contributes to reducing poverty and vulnerability of rural inhabitants, seeking the social inclusion of small producers, guaranteeing food and nutritional security for the population, and enhancing the contribution from agriculture to rural development.

Figures 2 and 3 show the relationship of each of the targets of SDG 2 and 12 with respect to the total of the 59 guidelines of agricultural policy. Figure 2 shows the emphasis of the action on doubling agricultural productivity and income (target 2.3), linked to export markets (targets $2 \mathrm{~b}$ and $2 \mathrm{c}$ ); that is, applying a productivist and economicist approach, which Clark [26] states as a neo-developmentalist orientation, but which, nevertheless, contributes to the decrease in food prices by improving access [27]. It is aligned with goal 2 via targeting the provision of irrigation infrastructure for productive purposes, maintenance of the genetic diversity of seeds, plants, animals, etc. to preserve agrobiodiversity and the traditional knowledge of producers (target 2.5). Target 2.2 does not coincide with any guideline, if addressing the problem of malnutrition is reflected in other intersectoral health policies, to face the problems of food insecurity, undernourishment, obesity, and overweight, among others. 


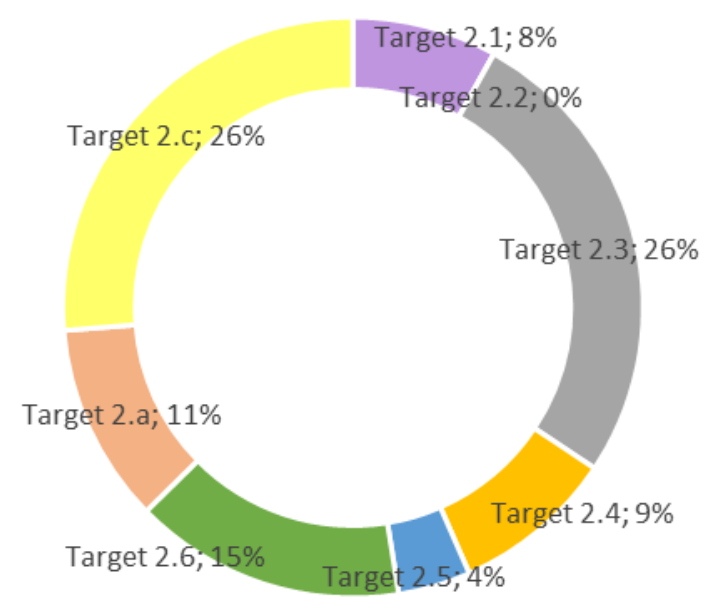

Figure 2. Agricultural policy and SDG 2.

Figure 3 shows the degree of agreement of the policy guidelines with the SDG 12 targets. There is a high relationship with targets 12.1, 12.2 and 12a, related to sustainable production and consumption, as well as strengthening the country's scientific and technological capacity through research, technological development, and extension. The relationship with targets 12.3, which have to do with the reduction of food and crops waste and management of waste generated by agricultural activity (target 12.5 ), as well as the enterprises responsibility over sustainability (target 12.6) and, as is the regulation of subsidies that promote the elimination of those that harm the sector (target 12c) is weak.

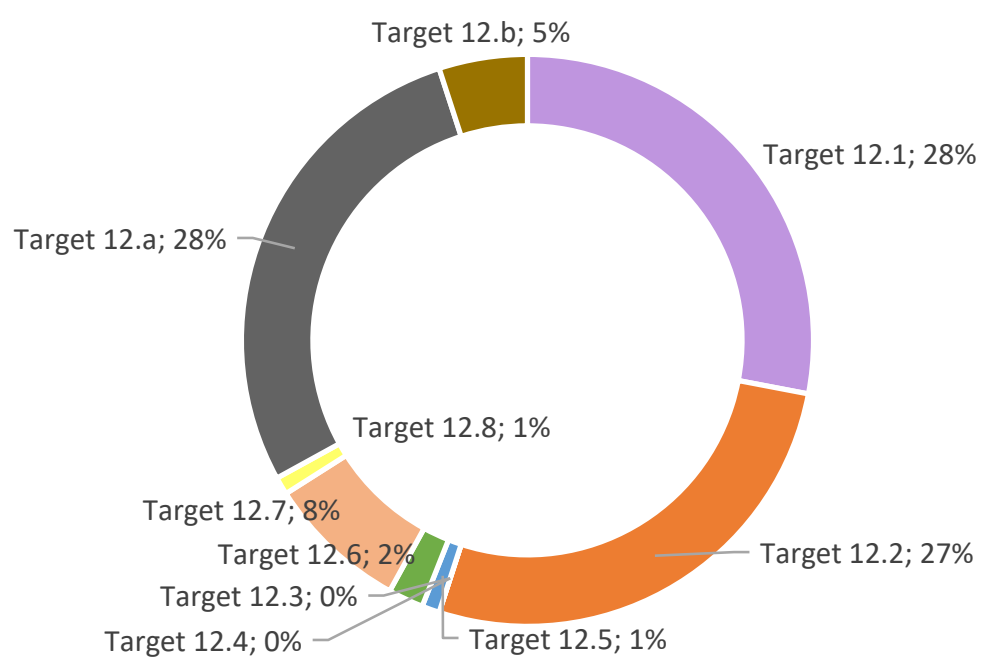

Figure 3. Agricultural policy and SDG 12.

The study by Chaudhary et al. [28] quantifies the performance status of the national food system of 156 countries in seven domains: nutrition, environment, food availability and affordability, socio-cultural well-being, resilience, food security, and waste. It concluded that the countries have very varied performance patterns. Those with high incomes obtain high scores in most of the indicators; however, on the environment and food 
waste, as well as those related to health, the scores are low. Therefore, it is important to act on several fronts to achieve all the targets of SDGs 2 and 12.

\subsection{The relationship between laws and SDG 2 (Table 3)}

The LORSA law is well aligned with SDG 2, highlighting the approach of agri-food subsidies and food insurance conducive to guaranteeing access and availability of food (target 2.1). An article to end forms of malnutrition is absent (target 2.2). The law emphasizes target 2.3 towards double productivity, access to land, and the application of resilient practices that ensure sustainability (target 2.4). At the Latin American level, food security and/or food sovereignty laws, in general, are considered with a high level of maturity since they show concern and will to guarantee the exercise of the right to food.

The LOASAA law is evidently close to targets 2.3, 2.4 and 2.5, which configure an adequate access to seeds for use in food production. However, the entry of transgenics that can affect biodiversity is left open, although restricted for research purposes. The articles aim to protect the plant genetic heritage, as well as the in situ and ex situ conservation of seeds and local knowledge (target 2.5). However, and contradictorialy it leaves the door open for transgenics, and restricts their use for research purposes. Sin embargo, contradictoriamente se deja abierta la entrada de transgénicos, aunque se restringe su uso para fines investigativos.

The LOTRTA law is related to SDG 2 since it emphasizes target 2.3 regarding access as such and land fertility, as well as the maintenance of ecosystems (target 2.4).

The LORHUAA law is decisive in ensuring food production (target 2.1). This law shows the need to change the conventional production model to one that includes resilient practices, maintenance of ecosystems, and adaptation to climate change (target 2.5), as well as the conservation of traditional knowledge related to community water management. It correlates to target 2 in terms of provision of irrigation infrastructure, research, and agricultural extension for food production purposes.

The LOEPS law covers fair-trade venture and recognizes ethical and responsable consumption (target 2c). There is agreement with the principle of the social and environmental responsibility of the organizations, guaranteeing that the commercialized products come from productive units that apply environmental and social criteria focused on their sustainability and quality (target 2.4). There is agreement with the principle of the social and environmental responsibility of the organizations, guaranteeing that the commercialized products come from productive units that apply environmental and social criteria focused on their sustainability and quality (target 2.4). With the implementation of the Ecuadorian fair-trade strategy in 2014, exports of these products have increased by $39.29 \%$ [26]. The development of forms of economic integration, such as preferably short chains and circuits to favour local economies, is established as a promotion measure, and the export of surpluses is aimed at, which is a global practice that at different rates and scales makes food get more expensive and have a deep ecological footprint that could be minimized (target 2c).

The LOSA law is related to SDG 2 by outlining the application of measures to guarantee food sovereignty with healthy and nutritious products (target 2.1). It is important to work on this premise, since health depends on the successful coexistence of the natural world and social relationships (28), that is, all effects from the practices (sustainable or not) carried out in the management of animals at some point reach human beings, with favourable and unfavourable consequences. Furthermore, the agricultural sector can be the generator of the best feeding conditions for the population. This effectiveness is based on the adoption of effective public and governance policies, which should define what type of food will be produced (according to economic, socio-cultural and dietary needs), in what quantities and volumes (to give access to all people continuously) and with sufficient quality (nutritious and safe).

At the same time, these policies must coordinate and provide support, resources, infrastructure, and supervision to all agents in the food chain to achieve the objectives of the 
entire system [11]. This law is linked with targets 2.3 and 2.5, which seek animal welfare, and with targets $2 \mathrm{a}$ and $2 \mathrm{c}$, mainly to generate research, technological development, and agricultural extension that allow creating local capacities as Peasant Family Farming territorial systems.

Table 3. Relationship between the articles of the laws and SDGs

\begin{tabular}{|c|c|c|c|c|c|c|}
\hline No. & LORSA & LASAS & LOTRTA & LORHUAA & LOEPS & LOSA \\
\hline Target 2.1. & $\begin{array}{c}1,12,13,18,20 \\
22,29,34 \\
\end{array}$ & & $8 f, 11,65,82$ & $\begin{array}{c}4 \mathrm{~d}, 39,71,84, \\
86,93,119,144 \\
\end{array}$ & $4,15,137$ & $3,4,9$ \\
\hline Target 2.2 . & $1,3,24,27,28,31$ & & & & & \\
\hline Target 2.3. & $\begin{array}{l}1,2,3,4,5,6,7,8,9 \\
13,14,16,17,18 \\
19,20,25,26,34\end{array}$ & $\begin{array}{l}14,18,19 \\
25,33,42 \\
46,47,51\end{array}$ & $\begin{array}{c}\mathrm{ff}, 7 \mathrm{~g}, 7 \mathrm{~h}, 8 \mathrm{e}, 8 \mathrm{f}, 9 \\
11,16,19,20 \\
23,24,27,35 \\
47,65,77 \\
\end{array}$ & 38 & 3 & 8,9 \\
\hline Target 2.4 . & $\begin{array}{c}2,3,4,6,7,13,14 \\
16,17,19,26\end{array}$ & $\begin{array}{c}14,17,18,48,49 \\
50,52\end{array}$ & $\begin{array}{c}7 \mathrm{k}, 13,46,48 \\
49,50,78\end{array}$ & $\begin{array}{c}8,11,12,13,14 \\
19,36,39,48,49 \\
50,63,64,71,83\end{array}$ & 4,137 & 5 \\
\hline Target 2.5 & $2,7,8,9,12,26,34$ & $\begin{array}{c}4,5,6,7,8,14 \\
18,20,21,24 \\
25,26,27,28,29 \\
30,31,36,37,56,57\end{array}$ & 23 & $\begin{array}{c}36,16,23,71 \\
73,77,78,82\end{array}$ & 4 & 9 \\
\hline Target 2.a & $\begin{array}{c}2,4,5,6,7,8,9,10,11 \\
13,23,25,26,34\end{array}$ & 14 & $7 e, 11,82$ & $\begin{array}{c}38,39,63 \\
64,84,41\end{array}$ & 3 & $4,8,9$ \\
\hline Target 2.b & $\begin{array}{c}2,14,19,20 \\
21,22,23,30,34\end{array}$ & & & & & \\
\hline Target 2.c & $\begin{array}{c}1,2,3,9,11,13,14 \\
19,20,21,22,23 \\
26,30,31,32,33\end{array}$ & & & & $\begin{array}{l}15 \\
137\end{array}$ & 4 \\
\hline
\end{tabular}

Note: The numbers under each law correspond to the articles of the laws.

Although it is true that the analysed laws complement each other, the gaps around addressing targets such as 2.2, referring to malnutrition and timely access to market information (target $2 \mathrm{c}$ ), are notable.

\subsection{The relationship between laws and SDG 12 (Table 4)}

The LORSA law is strongly related to target 12.1, which promotes sustainable production and, to a lesser degree, sustainable management of natural resources (target 12.2). It is worth noting that studies such as that carried out by Markkanen and Anger-Kraavi [29] point out that well-designed and carefully implemented climate change mitigation policies have the potential to generate social and economic benefits that can reduce poverty and provide opportunities for addressing economic, gender, and health inequalities. The establishment of public purchasing from agroecological, organic, and sustainable production stands out (target 12.7) and shows the change to clean production techniques. Several studies report that public purchases are policies that have been implemented in some countries through which products can be approached from farms to consumers of state services, such as schools, or through care programs for groups that are vulnerable or in extreme poverty [30]. In Ecuador, the government used to buy milk from small producers that was later processed by a private company to make dairy products and cookies that were delivered as part of breakfasts in public schools, high schools and geriatric centres.

The LOASAS law fits its articles with targets 12.2 and 12.a, regarding research and clean technology transfer for the production, conservation, and use of seeds to achieve 
sustainable management of these productive inputs. For its part, the LOTRTA law guarantees that the land fulfils its social function, that is, the sustainable production of food for the population (targets 12.1 and 12.2).

The LORHUAA law is fully related to targets 12.1 and 12.2 for production, sustainable management, and efficient use of natural resources. Several articles are consistent with targets 12.4, 12.5 and 12.6, related to focusing on the treatment of waste generated by agricultural activities.

The LOEPS law relates to targets 12.1 and 12.2 by recognizing and promoting the differentiated production, goods, and services that come from popular and solidarity economy organizations. Responsible consumption is concomitant with access to products from the alternative production models offered at inclusive or agroecological fairs that exist throughout the country.

The LOSA law establishes stimuli and incentives that promote compliance with good agricultural practices, which is a contribution to target 12.1. Good agricultural practices, in turn, reduce losses in the production chain and thus contributes to achieving target 12.3.

Table 4. Relationships between the articles of the laws and SDG 12

\begin{tabular}{|c|c|c|c|c|c|c|}
\hline No & LORSA & LASAS & LOTRTA & LORHUAA & LOEPS & $\begin{array}{c}\text { LOS } \\
\mathrm{A}\end{array}$ \\
\hline Target 12.1. & $\begin{array}{c}1,2,3,13,24 \\
25,27,28,29 \\
30,31,34 \\
\end{array}$ & & $\begin{array}{c}7 . c, 8.1,9 \mathrm{e} \\
12,13,46, \\
47,65,90 \\
\end{array}$ & $38,63,86,93,119$ & $4,137,138$ & $\begin{array}{l}3,8,9, \\
44,48\end{array}$ \\
\hline Target 12.2. & $3,5,6,14,34$ & $\begin{array}{l}7,14,17,18,19 \\
48,49,50,56,57\end{array}$ & $\begin{array}{c}12,50,77 \\
82\end{array}$ & $\begin{array}{c}4,8,13,14,36 \\
38,39,41,63 \\
64,71,72,73 \\
75,83,84,86,111 \\
\end{array}$ & 3,141 & $\begin{array}{r}3,4,5, \\
9,48\end{array}$ \\
\hline Target 12.3 & & 14 & & & & 44 \\
\hline Target 12.4 & 13 & 14 & & & & 8 \\
\hline Target 12.5 & & & 12 & 84 & & \\
\hline Target 12.6 & & & & & 4 & \\
\hline Target 12.7 & 20,34 & & & & 137 & \\
\hline Target 12.8 & 3,14 & 16,38 & & & & \\
\hline Target 12.a & $\begin{array}{c}2,9,10,11,25 \\
26,33,34\end{array}$ & $6,7,21,35$ & & & & 8 \\
\hline Target 12.b & $6,17,34$ & & & & & \\
\hline Target 12.c & & & & & & \\
\hline
\end{tabular}

Note: The numbers under each law correspond to the articles of the laws.

Targets $12 \mathrm{c}, 12.3,12.6,12 \mathrm{~b}$ and $12 \mathrm{c}$ are related to actions that are the responsibility of other sectors such as health or foreign trade, and these are included in intersectoral policies that aim at the country's rural development.

\section{Conclusions}

The SDGs, as a global commitment, require a larger Sate-driven effort that must be concretized in immediate and efficient actions that allow their achievement. In the Ecuadorian case, the country's anticipation in the approach of various policies and laws from the 2008 Constitution that pre-coincide with them should be highlighted. National development plans from 2008 consider sovereignty as a strategy to guarantee the right to food. 
The 2017-2021 National Development Plan reflects an articulation with all the SDGs, evidencing the cross-cutting nature of agricultural issues as given in the 2030 Agenda.

The impact on the agrarian question, having SDG 2 and 12 as the centre for rural development, means the establishment in the country of clear policies that go beyond the emphasis on productivity and production towards export items that leave aside the production of peasant families and rather strengthen the one that allows a rapid transition to sustainable production and consumption.

The multisectoral nature of agriculture and the alignment of public policies with SDGs 2 and 12 will underpin the achievement of other SDGs $(1,3,6,8,13,14$ and 15) that have an impact on the living conditions of sectors of the country's rural population that are in a vulnerable condition. The agricultural and livestock policy is weak in terms of the generation of synergies with other instances of the State in order to face structural problems such as malnutrition in rural areas and cities, which implies a problem of lack of comprehensiveness in the formulation of sectoral policies.

The study of these laws shows the need to strengthen local governance in favour of food sovereignty. This means a greater inclusion of the peasant productive sectors under the provisions of existing laws, which clearly establish participation in collective spaces for the debate and formulation of actions. There is still a need for the State and social organizations to speed up their incorporation into the processes of implementation, monitoring, and evaluation of public policies.

Structural changes regarding inequity in access and control of water and land, seed production, the use of GMOs, pollution, the solidarity economy, and trade and fair prices, in addition to the current policies and laws, demand governmental actions that change the vision of the productive model in the country, giving emphasis to Peasant Family Farming, thus guaranteeing food sovereignty; this will allow to face the effects of climate change and will strengthen rural development processes in the country.

\section{References}

1. ONU. Transformar nuestro mundo: la Agenda 2030 para el Desarrollo Sostenible. In Resolución aprobada por la Asamblea General del 25 de septiembre del 2015. https://unctad.org/meetings/es/SessionalDocuments/ares70d1_es.pdf

2. Gómez Gil, C. Objetivos de Desarrollo Sostenible (ODS): una revisión crítica. Papeles de Relaciones Ecosociales y Cambio Global 2017, 140:107-118. http://www.revistapapeles.es/datos/portada/ODS-revision-critica-C.Gomez.pdf

3. Sanahuja, J., Tezanos Vázquez, S. Del milenio a la sostenibilidad: retos y perspectivas de la Agenda 2030 para el desarrollo sostenible. Política y Sociedad 2017, 54(2). doi:10.5209/POSO.51926

4. Payne, T. Living in a less unequal World: The making of renewed progressive global policy. Institute for Public Policy Research. London, 2007.

5. Horn, P., Grugel, J. The SDGs in middle-income countries: Setting or serving domestic development agendas? Evidence from Ecuador. World Development 2018 doi:10.1016/j.worlddev.2018.04.005

6. Bengtsson, M., Alfredsson, E., Cohen, M., Lorek, S., Schroeder, P. Transforming systems of consumption and production for achieving the sustainable development goals: moving beyond efficiency. Sustainability Science 2018, 13(6),1533-1547. doi:10.1007/s11625-018-0582-1

7. Scherer, L., Behrens, P., de Koning, A., Heijungs, R., Sprecher, B., Tukker, A. Trade-offs between Social and Environmental Sustainable Development Goals. Environmental Science and Policy, 2018, 90:65-72. doi:10.1016/j.envsci.2018.10.002 
8. Von Braun, J., Birner, R. Designing Global Governance for Agricultural Development and Food and Nutrition Security. Review of Development Economics 2017, 21(2):265-284. doi:10.1111/rode.12261

9. Ribeiro, H., Jaime, P., Ventura, D. Alimentação e sustentabilidade. Estudos Avancados 2017, 31(89):185-198. doi:10.1590/s0103-40142017.31890016

10. Conejero, E. Globalización, gobernanza local y democracia participativa. Cuadernos Constitucionales de la Cátedra Fadrique Cerial 2002, 52153:13-31.

11. Mayett-Moreno, Y., López Oglesby, J. Beyond Food Security: Challenges in Food Safety Policies and Governance along a Heterogeneous Agri-Food Chain and Its Effects on Health Measures and Sustainable Development in Mexico. Sustainability, 2018, 10(12):4755. doi:10.3390/su10124755

12. Ruano de la Fuente, J. La gobernanza como forma de acción pública y como concepto analítico. In VII Congreso Internacional del CLAD sobre la Reforma del Estado y de la Administración pública. 8-11 de octubre. Lisboa, 2002.

13. Kanter, D., Schwoob, M-H. et al. Translating the Sustainable Development Goals into action: A participatory backcasting approach for developing national agricultural transformation pathways. Global Food Security 2016, 10:71-79. doi:10.1016/j.gfs.2016.08.002

14. Huitrón, A., Santander, C. La Agenda 2030 de Desarrollo Sostenible en América Latina y el Caribe: implicaciones, avance y desafíos. Revista Internacional de Cooperación y Desarrollo 2018, 5(1):3-11. http://revistas.usb.edu.co/index.php/Cooperacion/article/view/3591/2870

15. Chan, S., Boran, I. et al. Promises and risks of nonstate action in climate and sustainability governance. Wiley Interdisciplinary Reviews: Climate Change 2019, 10(3): e572. doi:10.1002/wcc.572

16. Berrone, P., Ricart, J., Duch, A., Bernardo, V., Salvador, J., Peña, J., Planas, M. EASIER: An evaluation model for public-private partnerships contributing to the sustainable development goals. Sustainability 2019, 11(8). doi:10.3390/su11082339

17. Dias, J., Gil, B., Reidsma, P., Giller, K., Todman, L., Whitmore, A., Van Ittersum, M. Sustainable development goal 2: Improved targets and indicators for agriculture and food security. Ambio 2019, 48(7): 685-698. doi:10.1007/s13280-018-1101-4

18. Bernardes Gil, J., Reidsma, P., Giller, K., Todman, L., Whitmore, A., Van Ittersum, M. Sustainable development goal 2: Improved targets and indicators for agriculture and food security. Ambio 2019, 48(7),685-698. doi:10.1007/s13280-018-1101-4

19. ONU. (2018). La Agenda 2030 y los Objetivos de Desarrollo Sostenible: una oportunidad para América Latina y el Caribe. Objetivos, metas e indicadores mundiales.

https://repositorio.cepal.org/bitstream/handle/11362/40155/24/S1801141_es.pdf

20. Rasul, G. Managing the food, water, and energy nexus for achieving the Sustainable Development Goals in South Asia. Environmental Development 2016, 18:14-25. doi:10.1016/j.envdev.2015.12.001

21. Campbell, B., Hansen, J., Rioux, J., Stirling, C., Twomlow, S., Wollenberg, E. Urgent action to combat climate change and its impacts (SDG 13): transforming agriculture and food systems. Current Opinion in Environmental Sustainability 2018, 34(13):13-20. doi:10.1016/j.cosust.2018.06.005

22. Butler, J., Bohensky, E. et al. Scenario planning to leap-frog the Sustainable Development Goals: An adaptation pathways approach. Climate Risk Management 2016, 12: 83-99. doi:10.1016/j.crm.2015.11.003

23. Humpenöder, F., Popp, A. et al. Large-scale bioenergy production: how to resolve sustainability trade-offs? Environmental Research Letters 2018, 13(2):024011. doi:10.1088/1748-9326/aa9e3b

24. Lay, J., Brandi, C., Das, R., Klein, R., Thiele, R., Scholz, I., Alexander, N. Coherent G20 policies towards the 2030 Agenda for Sustainable Development. G20 INSIGHTS 2017, 1-11. doi:10.03.2017 
25. Rudnick, J., Niles, M., Lubell, M., Cramer, L. A. comparative analysis of governance and leadership in agricultural development policy networks. World Development 2019, 117:112-126. doi:10.1016/j.worlddev.2018.12.015

26. Galsurkar, J., Singh, M. et al. Assessing National Development Plans for Alignment with Sustainable Development Goals via Semantic Search. In the Thirtieth AAAI Conference on Innovative Applications of Artificial Intelligence, 2018. http://www.aaai.org

27. Clark, P. Neodesarrollismo y una "vía campesina" para el desarrollo rural: Proyectos divergentes en la revolución ciudadana ecuatoriana. In Kay, C., Vergara-Camus, L., Eds. La cuestión agraria y los gobiernos de izquierda en América Latina. CLACSO, Buenos Aires, 2007. doi:10.2307/j.ctvn96g0z

28. Conceição, P., Levine, S., Lipton, M., Warren-Rodríguez, A. Toward a food secure future: Ensuring food security for sustainable human development in Sub-Saharan Africa. Food Policy 2016, 60: 1-9. doi:10.1016/j.foodpol.2016.02.003

29. Chaudhary, A., Gustafson, D., Mathys, A. Multi-indicator sustainability assessment of global food systems. Nature Communications 2018, 9(1):848. doi:10.1038/s41467-018-03308-7

30. Markkanen, S., Anger-Kraavi, A. Social impacts of climate change mitigation policies and their implications for inequality. Climate Policy 2019, 19(7):827-844. doi:10.1080/14693062.2019.1596873

31. Hespanhol, R. de M. Programa de Aquisição de Alimentos: limites e potencialidades de políticas de segurança alimentar para a agricultura familiar. Sociedade e Natureza 2013, 25(3):469-483. doi:10.1590/s198245132013000300003 